\title{
Contribution of Parenting Pattern to Moral Formation and Student's Class XI Learning Outcomes in Christian Religious Education at Vocational High School (SMK) Immanuel Medan In School Year 2015/2016
}

\author{
Elisabeth Sitepu
}

\begin{abstract}
This study aims to find out the significant contribution of parenting pattern according to repetition 6: 1-9 on moral formation of students, and to know the significant contribution of parenting pattern according to repetition 6: 1-9 to the result of student's learning outcome of Christian Education Subject at SMK Immanuel Medan. The population of this study were all students of class XI SMK Immanuel Medan which amounted to 190 people, and the number of samples included in this study were $(25 \% \times 190)=47.5$ people, then the study sample rounded to 48 people. Research design conducted by researcher using descriptive method. Descriptive method is a method in researching the status of human groups, an object, a set of conditions, a system of thought or a class of events in the present which aims to make description, picture or painting systematically, factually and accurately about the facts, the relationship between the phenomena being investigated. Based on hypothesis tested, it can be concluded that there is a significant contribution between parenting pattern according to repetition 6: 1-9 to moral formation (Y1), and there is a significant contribution parenting pattern according to repetition 6: 1-9 to student's learning outcomes of Christian Religious Education Subject (Y2).
\end{abstract}

Keywords: Parents Parenting Patterns, Moral Formation, and Learning Outcomes.

\section{BACKGROUND}

Active teenagers commit offenses, not just teenagers who generally do not have an influential exercise routine. Teenagers who are still sitting in school do violations that are very disturbing environment. The violations included school trespassing, smoking, fights between students, damaging public facilities, disrespecting parents, disrespecting, disturbing others, lacking respect for teachers, lack of discipline over time, lacking the beauty and cleanliness of the environment, and there are many more tendencies that often interfere with stability in general. If such problems are poorly given the attention and guidance of parents and teachers in school then such behavior will become rampant and will become a problem.

The low morale of teenagers can be seen as a manifestation of low self-discipline. In case the trigger is a negative environmental situation and condition. Parent's efforts will be achieved if the child has been able to control his own behavior with reference to the internalized moral values. Then the child will be able to anticipate the flow of globalization.

Moral is the most important thing that must be owned by a person in the life of society. Moral always refers to good or bad man. So that moral is the field of human life seen from the goodness of man . Moral values are used as a benchmark of human goodness. According to Muhammad Ali, "Moral means good and bad teaching to deeds, behavior, morals, duties, etc." (Muhammad Ali, 2000: 256). In other words, morals are related to the ability to discern right and wrong actions as controls in behavior. Moral is often regarded as a principle and a benchmark associated with right and wrong by a particular society, can also be interpreted as a behavior that conform to the true or false norms. Moral issues are one of the important aspects that need to be developed in children. Success or failure to invest capital value in childhood will determine the bad behavior of someone in the future.

Shape and evidence of deterioration among students is the presence of students who like to ditch during the hours of study, prefer to feel at home for long sitting in the school cafeteria is one of the deviant behavior of students. Decreasing in other morality values is the existence of students who do not do homework, lazy to learn, go at the time of study and the occurrence of fights between students. Dewa Ketut Sukarti said, "In the process of moral quality improvement must use various theories, perspectives, and terms of reference by involving various components of society, especially those concerned with the moral of the nation".

As the researcher has been seen in SMK Immanuel Medan some students still have good moral and learning outcomes. Just as the researcher have explained above. So for that, to improve morale as well as learning outcomes, Christian values should be given even more to the students and need the important role of 
parents from home. Parenting patterns that parents give to their children not only affect the behavior of the child but will also affect the learning achievement. Learning achievement is a result that is best achieved according to the ability of the child at a certain time to things done. When talking about learning achievement is not much to do with the school environment. School is a concept that has a double meaning. First, the school means a building or physical environment with all its equipment that is the place to organize a particular educational process for a particular human group. Second, the school means an activity or teaching and learning process. The school environment is the second environment that is also influential in determining learning achievement in school students designed to carry out guidance in a part of the development of human life. School continues the socialization process that has been implemented previously in the family and the environment around the neighbour, and prepare children to enter the next stage of life. In school teachers teach a variety of knowledge that has not been obtained by the child. Thus the pattern of care that is created in the family environment with education in the school environment, especially in the subjects of Christian Religious Education affect each other in children in achieving good learning outcomes in children for the future, which in this lesson has something to do with all forms of moral .

It can be said through the parenting pattern of the interaction between parents and children so as to direct the child and encourage the child to carry out the duties of responsibility as a child is to give motivation to the child to have a Christian morality and to plant spiritually so that children do not deviate from what is expected. Thus the pattern of parental care of a child will affect how the moral formation of the child, if the child's morale is well established it will also improve the learning outcomes of Christian Religious Education. It also improves the quality of good relationships between children and parents, children with teachers and children with their environment. Christian Religion Education needs to be instilled in children as early as possible.

Good relationships will be established when fellow family members have a good relationship or communication also between family members. When the children already have Christian values in theirself then certainly the childrem will have a good moral too. And when children have good morals then surely the children have an interest in studying Christian Religious Education. So education should first be taught in the family. In connection with the existence of the expectation gap from the above facts, the authors are interested in conducting a study on the contribution of parenting pattern according to Repetition 6: 1-9 To Moral Formation and Learning Outcomes of Student Class XI in SMK Immanuel Medan.

\section{A. Understanding Moral Formation}

\section{THEORETICAL REVIEW}

Understanding the formation in Indonesia Dictionary is the process, the way, the act of forming. While the moral in Latin is called mores, this word is understood as morality, which is about morality (mores) derived from mos or moris which means morality or good habits that apply to a particular group. According to Jason Lase, "moral is the doctrine of decency or in other words, the doctrine of principles and rules that can be studied systematically". According to Bertes K "Morality comes from the Latin adjective" moralist "has a meaning that is basically the same as morality there is only a more abstract tone. Morality of a deed with respect to good and bad ". To clarify the moral notion the researcher cites opinion (Sinngih D. Gunarsa, 1988: 36) which says:

Morality means the state of moral values in relation to social groups. Moral behavior is behavior that is in accordance with the moral values that exist in one group. Morality occurs when people take an attitude because they are aware of their obligations and responsibilities and not for profit. From the above it can be said that moral is the attitude and good deed/good etiquette applicable, which is used as a standard in dealing with social groups that grow because of awareness of responsibilities carried out without strings attached.

Factors that influence moral formation are parenting patterns, norms and culture, education, association and personality. Social norms are first known to the child through the parents. Therefore, it is very important in the moral development of children, learn the reasons of the things that may or may not and the good or bad. Then, the higher a person's education the higher the probability of understanding morality. Based on the above conclusions the researcher concludes that the moral formation expected of a child is a moral morality in accordance with the will of God.

\section{B. Understanding Christian Religous Education}

Learning outcomes are the abilities possessed by learners after they have received the learning experience. The number of participants obtained involves the cognitive, affective and psychomotor aspects.

\section{Results}

According to Poerwadarminta in Indonesian dictionary the result is something that is held (made) by effort or can also mean the opinion or the acquisition of the result, the result of the learning process (WJS Poerwadarminta, 1996: 337). 


\section{Learning}

Learning is something that is marked by a change in a person. Therefore a person is said to learn, if in the person there is a change of behavior. Changes in behavior take place in a relatively long time, so that person, from not able to be able. The changes will be evident throughout the behavior. Learning is generally interpreted as a change of individuals through experience, and not because of the growth and development of the body or characteristics of a person from birth. Humans learn a lot from birth, learning and development are closely related. From the understanding of learning that has been expressed by the experts, learning is the interaction between teachers, students and the environment to gain knowledge through a process.

\section{Learning Outcomes}

Learning outcomes are the abilities possessed by learners after they have received the learning experience. Some experiences gained by learners included the cognitive, affective and psychomotor aspects. Learning outcomes have an important role in the learning process because it will provide an information to teachers about the progress of learners in an effort to achieve learning objectives through the process of teaching and learning activities that after getting the information the teacher can develop and foster the activities of learners further good for both individuals and study groups.

According to Nana Sudjana (2009: 3) "Student learning outcomes are essentially behavioral changes as outcomes in a broad sense encompassing the cognitive, affective and psychomotor fields". Further Dimyati and Mudjiono say that "learning outcomes are the result of interactions of learning and teaching action. In terms of student learning is the end of teaching from the top of the teaching process ". (Dimyati and Mudiono, 2006: 3 4). In contrast to the opinion of Suratinah Tirtonegoro (2001: 43) which says "learning outcomes are an assessment of the results of learning activities in the form of sombol, numbers, letters and sentences that can reflect the results achieved by each student within a certain period".

Learning outcomes are an assessment of the student's ability determined in the form of numbers, the study of the students' ability after undergoing the learning process. Learning outcomes are the use of numbers on the results of tests or procedures of study in accordance with certain rules, or in other words to determine the students' absorption after mastering the subject matter that has been given. Learning outcomes are results obtained through impressions that result in changes in the individual as a result of learning activities.

Based on these opinions can be concluded that the learning outcome is a result obtained by students when he passed the learning process. Learning outcomes have an important role in the learning process because it will provide an information to teachers about the progress of learners in an effort to achieve learning objectives through the process of teaching and learning activities that after receiving the information the teacher can mengkusn and foster activities further learners For both individuals and study groups.

Christian Religious Education (PAK) is an education that contains teachings about the Christian faith. Christian Religion Education is an education that contains the teachings of Christianity by emphasizing the three aspects of education that is knowledge (cognitive), attitudes and values (affective), and skills (Psychomotor) based on Christian faith. PAK is an education aimed at teaching people to "see God" and "live happily". In this education the students are fully taught from the first verse of Genesis "in the beginning God created the heavens and the earth" until the meaning of creation in the church age today. The Bible study focuses on God's actions (Robert R. Boehlke, 1994: 128). PAK is the education that aims to teach the congregation to become disciples of Jesus Christ. They are expected to discover the will of God and then perform them in the local, national and international environment (Robert R. Boehlke 1994: 564).

Furthermore, according to Warner C.Graendorf quoted by Paulis Lilik Kristianto said that:

PAK is a biblical teaching process and learning, centered on Christ, and dependent upon the power of the Holy Spirit that nurtures each individual at all levels of growth, through present teaching toward the realization and experience of the plan of God's will through Christ in every aspect of life and equipping them for Effective ministry, centered on Christ the Great Teacher and the command that matures the disciples (Paul Lilik Kristianto, 2008: 4). PAK is an education that awakens everyone to God and his love in Jesus Christ so that they know who they really are, as they grow, as sons of God in Christian fellowship, fulfilling the common vocation as disciples of Jesus in the world and remaining in Christian hope.

\section{Understanding Parenting Patterns}

Parents are a family component consisting of fathers, and mothers and are also the result of a legitimate marriage that can form a family. Parents have the responsibility to educate, nurture and guide their children to achieve certain stages that will enable the child to be ready for social life. Slamento said: "That the parents should educate their children with affection, caring and punishing those who violate the rules that have been made together" (Slamento, 3003: 61).

Parenting patterns greatly affect the morale and interests of children in their daily lives. If parents take good care of their children then, the child's morale will be good. Parents who are busy with activities outside or 
who are busy with their work, children will be ignored and not paid attention. Families in relation to children are identified as the most caring place or caregiver. In the family it is the first time that children have direct early experience that will be used as their future life supplies through physical, social, mental and emotional and spiritual exercises. Suparlan defines that: "the family is a social group made up of fathers, mothers and children. Social relationships among family members are relatively fixed and are based on marriage, blood or adoption bonds. The relationship between the family is imbued with an atmosphere of love and a sense of responsibility "(Suparlan, 1998: 30). From the above opinion can be concluded that the role of parents is a function that is played by parents who are in a position or a particular situation with certain characteristics or specifications as well.

\section{RESEARCH METHODS}

The method used by researchers is descriptive method. Descriptive method is a method in researching the status of human groups, an object, a set of conditions, a system of thought or a class of events in the present which aims to create a description, picture or painting systematically, factually and accurately about the facts, And the relationship between the phenomena investigated. The research data was collected by using questionnaire, so the research can be done through survey, after all the problems have passed, this research can be called ex post facto. Ex post facto is a study conducted to examine the events that have occurred and then look back, to determine the factors that can cause the incident.

\section{Population and Sample}

In conducting this research, researcher set a target and area of research called the population. Population is the whole research in which there is a subject that can be used as a source of data for a researcher. Suharsimi Arikunto (1997: 102) says that: Population is the subject of research, if one wants to examine all the elements that exist in the area of research, the study is a population of studies and research done if researcher want to see the twists and turns because the subject includes everything contained in the population so-called census. Objects on the population is researched the results, analyzed, concluded. And this conclusion applies to the entire population.

Based on the above quote, the researchers determined that the population of this study is all students of class XI in SMK Immanuel Medan which amounted to 190 people.

As expressed by Ridwan (2005: 65) that "if the population of 190 people at least $25 \%$ of the population is taken into the study sample. The technique of determining the sample of research used by the technique of random sampling samples (simple random) ". From the above opinion, the number of samples included in this study is $(25 \% \times 190)=47.5$ people. Then the study sample rounded up to 48 people. Thus it is concluded that the number of samples of this study is as many as 48 people taken randomly in the same class by using a random sampling technique (with random).

\section{RESULTS AND DISCUSSION}

\section{The Result of Coefficient Correlation Analysis}

After the normality test requirements, linearity and significance tests are met, then the hypothesis can be tested with product moment correlation $\left(\mathrm{r}_{\mathrm{xy}}\right)$ and significant correlation done by using $\mathrm{t}$ test.

1. Calculation of Correlation between Parenting Pattern by Repetition 6: 1-9 (X) with Moral Formation (Y1) With value of $r_{\text {test }}$ and $r_{\text {value }}$ for $\mathrm{N}=48$ at $5 \%$ significant level where the value of $r_{\text {table }}$ constant is 0.284 . Thus it can be seen that value of $r_{\text {test }}>r_{\text {table }}(0,720>0,361)$, so correlation $X$ to $Y 1$ is significant.

And based on t distribution list at significant level $5 \% \mathrm{dk}=\mathrm{N}-2=46$, obtained $\mathrm{t}_{\text {table }}$ at that level of 1.684. Thus the value of $t_{\text {test }} 9,78>t_{\text {table }} 2,000$. So it can be concluded that there is a meaningful contribution Parenting Pattern according to Repetition 6: 1-9 to Moral Formation (Y1).

2. Calculation of Correlation between Parenting Patterns by Repetition 6: 1-9 (X) with Student's Learning Outcomes of Christian Religious Education (Y2)

With value of $r_{\text {test }}(1,2)$ with $r_{\text {table }}$ for $\mathrm{N}=48$ at $5 \%$ significant level, where the $r_{\text {table }}$ constant is 0.284 . Thus it can be seen that $r_{\text {value }}>r_{\text {table }}(0,302>0,248)$, so correlation $X$ to $Y 2$ is significant. Thus, based on the $t$ distribution list at a significant level of $5 \% \mathrm{dk}=\mathrm{N}-2=46$, the value of $\mathrm{t}_{\text {table }}$ at that level is 1.701 . Thus the value of $t_{\text {test }} 2.047>t t_{\text {table }} 1.684$. So it can be concluded that there is a significant contribution Parenting Pattern According Repetition 6: 1-9 to Student's Learning Outcomes of Christian Religious Education (Y2).

\section{Discussion of Research results}

From the results that have been done, then as a result of this study to prove the initial hypothesis as follows:

1. There is a contribution The Parenting Pattern by Repetition 6: 1-9 (X) to Moral Formation (Y1). With value of $r_{\text {test }(1,2)}$ and $r_{\text {table }}$ for $\mathrm{N}=48$ at $5 \%$ significant level, where the $r_{\text {table }}$ constant is 0,284 . Thus it can be seen 
that the value of $r_{\text {test }}>r_{\text {table }} 1(0.720>0.361)$, so the correlation of $\mathrm{X}$ to $\mathrm{Y} 1$ is significant. And based on $\mathrm{t}$ distribution list at significant level $5 \% \mathrm{dk}=\mathrm{N}-2=46$, obtained $\mathrm{t}_{\text {table }}$ at that level of 1.684. Thus the value of $\mathrm{t}_{\text {test }} 9,78>\mathrm{t}$ table 2,000. So it can be concluded that there is a meaningful contribution Parenting Pattern according to repetition 6: 1-9 to Moral Formation (Y1).

2. There is a contribution Parenting Pattern according to Repetition 6: 1-9 (X) with Student's Learning

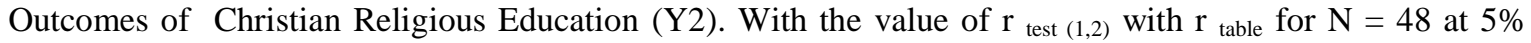
significant level, where the $r_{\text {table }}$ constant is 0.284 . Thus it can be seen that the value of $r_{\text {test }}>r_{\text {table }}(0,302>$ 0,248 ), so correlation $\mathrm{X}$ to $\mathrm{Y} 2$ is significant. And based on t distribution list at significant level $5 \% \mathrm{dk}=\mathrm{N}-$ $2=46$, obtained $t_{\text {table }}$ at that level of 1.701. Thus the value of $t_{\text {test }} 2.047>t$ table 1.684. So it can be concluded that there is a significant contribution The Parenting Pattern According Repetition 6: 1-9 to Student's Learning Outcomes of Christian Religious Education (Y2).

\section{Conclusion}

\section{CONCLUSIONS AND SUGGESTION}

Based on the results of the research, it can be concluded as follows:

1. There is a contribution The Parenting Parenting by Repetition 6:1-9 (X) to Moral Formation (Y1). By $r_{\text {test }}>$ $r_{\text {table }}(0,720>0,284)$, so correlation $X$ to $Y 1$ is significant. And based on t distribution list at significant level $5 \% \mathrm{dk}=\mathrm{N}-2=46$, value of $\mathrm{t}_{\text {table }}$ at that level equal to 1,684 . Thus the value of $\mathrm{t}_{\text {test }} 9,78>\mathrm{t}_{\text {table }} 2,000$. So it can be concluded that there is a meaningful contribution Parenting Pattern according to Repetition 6: 1-9 to Moral Formation (Y1).

2. There is a contribution The Parenting Pattern by Repetition 6: 1-9 (X) with Student's Learning Outcomes of PAK (Y2). With value of $t_{\text {test }}>\mathrm{t}_{\text {table }}(0,302>0,248)$, so correlation $\mathrm{X}$ to $\mathrm{Y} 2$ is significant. Based on $\mathrm{t}$ distribution list at significant level $5 \% \mathrm{dk}=\mathrm{N}-2=46$, obtained $\mathrm{t}_{\text {table }}$ at that level of 1.701 . Thus the value of $\mathrm{t}_{\text {test }} 2.047>\mathrm{t}$ table 1.684. So it can be concluded that there is a significant contribution The Parenting Pattern According to Repetition 6: 1-9 to Student's Learning Outcomes of Christian Religious Education (Y2).

\section{Suggestion}

From the results of research above, the research give suggestion as below:

1. Parenting Patterns by Repetition 6: 1-9 should be deepened. Parenting Pattern to child is very important both physically and spiritually. Christian parents must educate with the true love and discipline and teach their children repeatedly. Thus, it is expected that children will be away from negative behaviors that damage themselves and others, because they already have a firm grip, solid foundation, have a clear purpose of life and able to live independently steadfast in its faith.

2. In the formation of morals, certainly influenced by several factors. Whether it's internal and external. These factors must have a negative and also positive. So Parents should be more to give good care to their children, so that children do not do negative things like smoking, free sex, reckless, and so forth in the future children have a better moral.

3. Student's Learning Outcomes of Christian Religious Education at school can also increase, if Parenting Pattern at home are able to provide good education. Then the results of learning will increase from psychomotor, cognitive, and affective results.

\section{REFERENCEES}

[1]. Ali Muhammad. 2000. Kamus Lengkap Bahasa Indonesia Modern. Jakarta : Amani

[2]. Ardinawata Rustana. 1986. Proses Belajar Mengajar. Jakarta: Proyek Peningkatan Mutu Pendidikan Guru Agama

[3]. Baxter J. Sidlow. 1983. Menggali Isi Alkitab I: Kejadian-Ulangan. Jakarta: BPK Gunung Mulia

[4]. Boehkle Robert R. 1994. Sejarah Perkembangan Pemikiran dan Praktek PAK Dari Yohanes Amos Comenius sampai Perkembangan PAK di Indonesia. Jakarta: BPK Gunung Mulia

[5]. Borrong Robert P. 2006. Etika Seksual Kontemporer. Bandung: Ink Media

[6]. Brownlee Malcolm. 2000. Pengambil Keputusan Etis dan Faktor-faktor Di Dalamnya. Jakarta: BPK Gunung Mulia

[7]. Budiyana Hardi. 2011. Dasar-Dasar Pendidikan Agama kristen. Yogyakarta : ANDI

[8]. Daradjat Zakiah. 1989. Kesehatan Mental. Jakarta: PT Gramedia Pustaka Utama

[9]. Gea Antonius Atosokhi. 2002. Relasi Dengan Sesama. Jakarta: PT Elex Media Komputindo

[10]. Gunarsa Singgih D. 1998. Psikologi Perkembangan. Jakarta : BPK Gunung Mulia

[11]. Gunarsa Singgih D. 1981. Psikologi Untuk Keluarga. Jakarta: BPK Gunung Mulia

[12]. Hamalik Oemar. 2013. Kurikulum dan Pembelajaran. Bandung: Bumi Aksara, 2013

[13]. Handoko dan Theo Riyanto .2005. Pendidikan Pada Usia Dini. Jakarta: Grasindo 
Contribution of Parenting Pattern to Moral Formation and Learning Outcomes of Christian ..

[14]. K. Bertes. 1994. Etika. Jakarta: Gramedia Pustaka Utama

[15]. Kristiano Paulus Lilik. 2008. Prinsip dan Praktek Pendidikan Agama Kristen. Yogyakarta : ANDI

[16]. Lase. Jason. 2007. Pendidikan Agama Kristen di Perguruan Tinggi Umum. Jakarta: BMI

[17]. Lembaga Alkitab Indonesia. 2007. Alkitab Perjanjian Baru. Jakarta: LAI

[18]. Molionoswski. 1930. Principle Of Legitimacy Sebagai Basis Keluarga. Jakarta: Kesaint Blanc

[19]. Mudjiono dan Dimyati . 2006. Belajar dan Pembelajaran. Jakarta: Rhineka Cipta

[20]. Mulyasa E. 2005. Menjadi Guru profesional. Bandung: PT Remaja Rosda Karya

[21]. Muhammad Asrori dan Muhammad Ali. 2008. Psikologi Remaja. Jakarta: PT Bumi Aksara

[22]. Munadi Rusman. 2012. Belajar dan Pembelajaran Berbasis komputer Mengembangkan Profesionalisme Guru Abad 21. Bandung: ALFABETA

[23]. Nainggolan John M. 2007. Menjadi Guru Agama Kristen. Bandunng: Generasi Info Media

[24]. Nazir Moh. 1998. Metode Penelitian. Jakarta: TP

[25]. Richard Eyre \& Linda. 1999. Mengajarkan Nilai-Nilai Kepada Anak. Jakarta: PT Gramedia Pustaka Utama

[26]. Sidjabat B.Samuel. 1993. Menjadi Guru Profesional Sebuah Perspektif Kristiani. Bandung: Yayasan Kalam Hidup

[27]. Slameto. 2003. Belajar dan Faktor-Faktor Yang Mempengaruhinya. Jakarta, PT Rineka Cipta

[28]. Sudjana Nana. 2009. Penilaian Hasil Prosese Belajar Mengajar. Bandung: PT Remaja Rosdakarya

[29]. Suhana Cucu. 2014. Konsep Strategi Pembelajaran. Bandung: Reflika Aditima

[30]. Sukardi Dewa Ketut. 2000. Pangantar pelaksanaan program bimbingan dan konseling di sekolah. Bandung : PT Rineka Cipta

[31]. Suparlan. 1998. Keluarga dan Anak-anak. Jakarta: BPK Gunung Mulia

[32]. Syah Muhibbin. 2004. Psikologi Pendidikan dengan Pendekatan Baru. Bandung: PT. Remaja Rosdakarya

[33]. Syaiful Bahri Dzamarah \& Aswan Zain. 2006. Strategi Belajar dan Mengajar. Jakarta: Rineka Cipta

[34]. Tirtonegoro Suratinah. 2001. Anak Super Normal dan Program Pendidikannya. Jakarta: Bina Aksara

[35]. Unell J.Wyckoff. 1994. Disiplin Tanpa Teriakan atau Pukulan. Jakarta: Binarupa Aksara

[36]. Winata Udin S. 2007. Teori Belajar dan Pembelajaran. Jakarta: Pusat Penerbit Universitas Terbuka

[37]. Winkle Uj.S .1991. Psikologi Perkembangan Jakarta. Jakarta: Grafindo

[38]. Zuriah Nurul. 2007. Pendidikan Moral dan Budi Pekerti Dalam Perseftif Perubahan. Jakarta: Bumi Aksara 